\title{
Application of mangrove (Bruguiera gymnorrhyza) leaves' extract on chewing gum as an inhibitory agent against dental caries causing bacteria
}

\author{
${ }^{1, *}$ Hardoko, ${ }^{1}$ Agung, P.R. and ${ }^{2}$ Halim, Y. \\ ${ }^{1}$ Faculty of Fisheries and Marine Sciences, Brawijaya University, Jalan Veteran No. 1 Malang, 65113, East \\ Jawa, Indonesia \\ ${ }^{2}$ Food Technology Study Program, Faculty of Science and Technology, Universitas Pelita Harapan, Jalan \\ M.H. Thamrin Boulevard, Lippo Karawaci, Tangerang 15811, Indonesia
}

\section{Article history:}

Received: 3 March 2021

Received in revised form: 14

April 2021

Accepted: 28 June 2021

Available Online: 20

February 2022

\section{Keywords:}

Bruguiera gymnorrhyza,

Chewing gum,

Dental caries,

Inhibitor,

MIC

DOI:

https://doi.org/10.26656/fr.2017.6(1).158

\begin{abstract}
Mangrove Bruguiera gymnorrhyza contains bioactive compounds, such as tannin, saponin, and flavonoid. These are antimicrobial properties and have the potential to inhibit dental caries causing bacteria. Chewing gum incorporated with xylitol could inhibit plaque accumulation and demineralization at the early stages of dental caries and reduce the number of Streptococcus mutans in the mouth. This research was aimed to determine the inhibition power of B. gymnorrhyza leaves extract and its application on chewing gum towards Steptococcus mutans and Streptococcus viridans. The method used was experimental, consisting of the first stage with the treatment of different extract concentrations $(5 \mathrm{mg} / \mathrm{mL}, 10 \mathrm{mg} / \mathrm{mL}, 15 \mathrm{mg} / \mathrm{mL}, 20 \mathrm{mg} / \mathrm{mL}, 25 \mathrm{mg} / \mathrm{mL})$ and a second stage with the treatment of different extract concentration in the chewing gum (2 MIC, 3 MIC, 4 MIC, and 5 MIC). Results showed that B. gymnorrhyza leaves extract can be categorized as a strong inhibitor against dental caries causing bacteria with MIC value of $1.62 \mathrm{mg} / \mathrm{mL}$ towards Steptococcus mutans and $1.35 \mathrm{mg} / \mathrm{mL}$ towards Streptococcus viridans. The application of B. gymnorrhyza leaves extract at 3 MIC in chewing gum produced the most preferred chewing gum and has strong inhibitory activity against dental caries causing bacteria with inhibition diameter of $10.26 \mathrm{~mm}$ towards Steptococcus mutans and inhibition diameter of $12.51 \mathrm{~mm}$ towards Streptococcus viridans. It is also very safe to consume with an $\mathrm{LC}_{50}$ value of $10502 \mathrm{mg} / \mathrm{mL}$.
\end{abstract}

\section{Introduction}

Bruguiera plant, which is locally known as "lindur", is found abundantly in tropical regions. In Indonesia, this plant is found in Java, Sumatra, Borneo, Mollucas, and Bali (Jacoeb et al., 2013). This type of mangrove has been used in several human needs, such as a food ingredient, as firewood, and also used in traditional medicine. Traditionally, mangrove Bruguiera gymnorrhyza fruit is used as medicine for curing fungal infection in the tongue (Candidiasis), baby stomach cleanser, and treating skin rashes (Abubakar et al., 2019). Mangrove Bruguiera cylindrical is used to treat eye pain, while the bark of Bruguiera exaristata is used to treat bleedings, and the Bruguiera gymnorhyza flower to treat ear infection (Purnobasuki, 2004).

The utilization of Bruguiera plant parts as traditional medicine indicates the presence of a bioactive compound that can cure diseases as it is antimicrobial. The root

*Corresponding author.

Email: hardoko@ub.ac.id extract of Bruguiera gymnorhyza could inhibit E. coli and S. aureus (Audah et al., 2020), Bruguiera gymnorhyza leaves extract inhibits Delftia sp., Bacillus subtilis, Pseudomonas aeruginosa and Klebsiella pneumoniae (Kurniasih and Halimah, 2019), polyisoprenoid from Bruguiera gymnorhyza leaves inhibits the growth of E. coli and S. aureus (Sumardi et al., 2018; Renaldi et al., 2018). Other types of mangroves also possess antimicrobial activity. For example, mangrove Avicennia marina, Sonneratia caseolaris, Ceriops tagal, Rizhopora apiculata, and Sonneratia alba have antibacterial activity against Salmonella enterica serovar Typhi and Listeria monocytogenes (Mustopa et al., 2015), mangrove $R$. mucronata leaves have antibacterial activity towards Aeromonas hydrophila (Mikchaell et al., 2018). Moreover, Avicennia marina leaves has antibacterial activity towards E. coli dan $S$. aureus (Audah et al., 2020), mangrove Lumnitzera littorea leaves have antimicrobial activity against Bacillus cereus, Published by Rynnye Lyan Resources 
Pseudomonas aeruginosa, Candida albicans, Cryptococcus neoformans (Saad et al., 2011), mangrove Avicennia marina leaves have antibacterial activity towards E. coli and S. aureus (Renaldi et al., 2018), Avicennia sp. leaves inhibits $E$. coli and $S$. aureus (Alhaddad et al., 2019), the stem of Nypa fructicans inhibits Bacillus subtilis, whereas the Nypa fructicans leaves inhibit Pseudomonas aeruginosa and Klebsiella pneumoniae (Kurniasih and Halimah, 2019). Other research has also reported that leaves, bark, and root of Rhizophora apiculate has the potential to inhibit $P$. aeruginosa, S. aureus, Streptococcus sp., and E. coli (Ciptaningrum and Putri, 2019), L. racemosa and $A$. marina has shown inhibitory activity against $S$. aureus and Proteus sp. which are resistant to antibiotics (Abeysinghe, 2010), polyisoprenoid from leaves of Avicennia, Barringtonia, Calophyllum, Nypa, and Pandanus inhibits the growth of E. coli and $S$. aureus (Sumardi et al., 2018).

Antimicrobial activity of mangrove Bruguiera and other types of mangrove could inhibit pathogenic bacteria, particularly pathogenic bacteria in food products. Therefore, Bruguiera plant has the potential to be used as a natural antimicrobial source to be applied on several food products, such as fishery products (Hastarini et al., 2014). Bruguiera could be a natural antimicrobial agent because it contains bioactive compounds, such as steroid, triterpenoid, saponin, flavonoid, alkaloid and tannin (Purnobasuki, 2004; Doughari, 2012).

On the other hand, dental problems are a reoccurring problem in many countries including Indonesia. A common dental problem is dental caries. In Indonesia, dental caries is found in both children and adults with a prevalence of $85-99 \%$. In 2017, WHO stated that permanent dental caries ranked the first and primary dental caries ranked the twelfth as the most common dental health problem in the world (Kassebaum et al., 2017). Bacteria that play roles in dental caries are $S$. mutans and S. viridans (Fatmawati, 2015).

There are 3 theories regarding the dental caries mechanisms, which are proteolysis theory, proteolyticchelation theory, and chemo parasitic or acidogenic theory. The acidogenic theory explains that dental caries formation is caused by acid produced by microorganisms' action towards carbohydrates (Ramayanti and Purnakarya, 2013). Streptococcus viridans in the oral cavity could synthesize polysaccharides, such as dextran from sucrose to form attachment and form colonies with other bacteria, which subsequently form dental plaque. Streptococcus mutans could ferment carbohydrates into acid that causes enamel demineralization continuously to form cavities and cause dental caries (Ramayanti and Purnakarya, 2013; Haerazi et al., 2014). Negative effects from dental caries could be bleeding, infection, loss of tooth bone, wobbly tooth and even tooth loss (Andriani and Rizka, 2014). Furthermore, dental caries can indirectly cause cardiovascular diseases (Cotti et al., 2011).

Prevention of dental caries can be done by inhibiting the bacteria causing it (Purnamasari et al., 2010). Inhibition towards dental causing bacteria can be done using antibiotics or natural antimicrobial agents. However, the use of antibiotics could cause new phenomena, such as resistance, allergic reaction, and toxic reaction (Newman et al., 2006). Meanwhile, mangrove Bruguiera has the potential to be used as a natural antibacterial agent to prevent dental caries. It is based on its capability to inhibit pathogenic bacteria. The leaves and bark of Bruguiera gymnorryza contain bioactive compounds, such as tannin, saponin, flavonoid, steroid, and terpenoid that possess antimicrobial properties (Anggraini et al., 2018).

A natural antimicrobial agent to prevent toothache has been applied in toothpaste and mouthwash (Siregar et al., 2011; Astuti and Meilawaty, 2013; Khairani et al., 2017; Paksi et al., 2018; Suhendar and Fathurrahman, 2019). Therefore, a more effective alternative to inhibit bacterial growth and is more preferred by consumers is required. One of the potential alternatives is the application of chewing gum. The consideration is that chewing gum could stimulate saliva secretion, increase the $\mathrm{pH}$ of plaque and saliva, using it as an oral cavity cleanser. The addition of xylitol in chewing gum inhibits plaque accumulation and enamel demineralization, increase remineralization in the early stage of dental caries and reduce the number of $S$. mutans (Hidayati et al., 2014). Another reason is that chewing gum is popular, it stays longer inside the mouth, and other ingredients assisting in the inhibition of bacteria can be added and increase consumers' acceptance.

Based on those considerations, research is required to determine Bruguiera gymnorrhyza leaves extract inhibitory activity against $S$. mutans and $S$. viridans, as well as to determine the potency of Bruguiera gymnorrhyza leaves extract in chewing gum to inhibit dental caries causing bacteria, namely $S$. mutans and $S$. viridans.

\section{Materials and methods}

\subsection{Materials and equipment}

The material used was mangrove Bruguiera gymnorrhyza leaves which are old and green-coloured, obtained from MIC (Mangrove International Center), Surabaya, East Java, Indonesia. Materials for chewing 
gum making were erythritol gum base powder "Niranbio", liquid Stevia sweetener, glucose syrup "Rose Brand", xylitol, mannitol, mangrove B. gymnorrhyza leaves extract and aquadest. Materials for analysis were Steptococcus mutans and Streptococcus viridans bacteria, obtained from the culture collection of Faculty of Medicine, Brawijaya University, Artemia salina Leach, Nutrient agar (NA), and dimethyl sulfoxide (DMSO).

Equipment used for chewing gum making were stove, pan, digital balance "Camry EK505", sieve, and tray. Equipment used for chemical analysis were incubator "Memmert", inoculating loop, $100 \mu \mathrm{L}$ micropipette "ToPette Nesco", autoclave "E-Scientific", Petri dish and glassware.

\subsection{Research method}

The method used in this research was an experimental method that was performed in two-stage experiments. In the first stage of research, the treatment used was different concentrations of mangrove $B$. gymnoryza leaves extract from 5, 10, 15, 20, and $25 \mathrm{mg} /$ $\mathrm{mL}$ against $S$. mutans and $S$. viridans. In the second stage of research, the experiment was done by adding the extract with concentrations of 2 MIC, 3 MIC, 4 MIC, 5 MIC into chewing gum and determining its inhibition towards S. mutans and S. viridans. The experimental design used was Randomized Full Factorial Design with 4 replications. Parameters observed were antibacterial activity in terms of inhibition zone and Minimum Inhibitory Concentration (MIC), hedonic organoleptic test, and toxicity of chewing gum. All research data were analyzed using Anova (Analysis of Variance) with Tukey Post Hoc test using SPSS Program, version 20.

\subsubsection{Extraction of mangrove Bruguiera gymnorrhyza leaves}

Extraction of mangrove B. gymnorrhyza leaves was done using the maceration method at room temperature (Adi and Usman, 2017). Initially, mangrove leaves were washed and dried at room temperature until the colour became brownish. The dried samples were reduced in size using a disc mill and sieved with a 60-mesh sieve. Mangrove leaves powder obtained was macerated using an ethanol solvent with a ratio of 1:4 (w/v) for $72 \mathrm{hrs}$. The macerate was then filtered using filter paper and the filtrate was evaporated using a rotary evaporator at $40^{\circ} \mathrm{C}$ until the concentrated extract was obtained.

\subsubsection{Chewing gum making procedure}

MIC value as the basis of chewing gum formulation was obtained from the diameter of inhibition shown in Table 1. The production of chewing gum is carried out according to the research by Raithore and Peterson (2018) with slight modification. The formulation used can be observed in Table 2 .

Table 1. MIC value of B. gymnorrhyza leaves extract

\begin{tabular}{lc}
\hline \multicolumn{1}{c}{ Bacteria } & MIC $(\mathrm{mg} / \mathrm{mL})$ \\
\hline Streptococcus mutans & 1.62 \\
Streptococcus viridians & 1.35 \\
\hline
\end{tabular}

Table 2. Formulation of chewing gum making

\begin{tabular}{lcccc}
\hline \multirow{2}{*}{ Ingredients } & \multicolumn{4}{c}{ Treatment } \\
\cline { 2 - 5 } & $2 \mathrm{MIC}$ & $3 \mathrm{MIC}$ & $4 \mathrm{MIC}$ & $5 \mathrm{MIC}$ \\
\hline Extract $(\mathrm{mg} / \mathrm{mL})^{*}$ & 3.24 & 4.86 & 6.48 & 8.10 \\
Erythritol $(\mathrm{g})$ & 25.00 & 25.00 & 25.00 & 25.00 \\
Glucose $(\mathrm{g})$ & 27.00 & 27.00 & 27.00 & 27.00 \\
Xylitol $(\mathrm{g})$ & 18.00 & 18.00 & 18.00 & 18.00 \\
Stevia $(\mathrm{mL})$ & 0.13 & 0.13 & 0.13 & 0.13 \\
Mannitol $(\mathrm{g})$ & 5.00 & 5.00 & 5.00 & 5.00 \\
\hline
\end{tabular}

*MIC value of extract was obtained from 1st stage research

Erythritol gum base powder, glucose syrup, stevia, xylitol, and mangrove B. gymnorrhyza leaves extract were placed inside a double boiler (a stacked pan, in which a bottom pan was filled with water to be boiled and a smaller size pan on the top of it). The double boiler was heated with medium heat on a stove and stirred until it became warm and viscous. Erythritol gum base powder, citric acid, and mangrove leave extract were put on top of it and stirred using a spoon. After it cooled down, mannitol was smeared onto both hands and the dough was mixed for about 15 mins. Afterwards, the dough was rolled, cut, and was ready for analysis.

\subsubsection{Antibacterial activity assay}

Antibacterial activity assay was performed using the well-diffusion method (Bloomfield, 1991; Parhusip and Sitanggang, 2011). Initially, each culture of $S$. mutans and $S$. viridans was rejuvenated in Nutrient Broth for 24 hours at $37^{\circ} \mathrm{C}$. About $10 \mathrm{~mL}$ of sterile Nutrient Agar (NA) was poured into a Petri dish and left to solidify at room temperature. Each culture $(100 \mu \mathrm{L})$ was placed onto the surface of the media, aseptically spread thoroughly using a triangle and left for 5 mins. Wells with a diameter of $6 \mathrm{~mm}$ were made on the media that have been added with bacteria. Mangrove leaves extract with a volume of $60 \mu \mathrm{L}$ with concentrations of $5 \mathrm{mg} / \mathrm{mL}$, $10 \mathrm{mg} / \mathrm{mL}, 15 \mathrm{mg} / \mathrm{mL}, 20 \mathrm{mg} / \mathrm{mL}, 25 \mathrm{mg} / \mathrm{mL}$ were placed into the wells and incubated at $37^{\circ} \mathrm{C}$ for $24 \mathrm{hrs}$. The clear zone formed around the wells was the zone of inhibition and was measured using Vernier calliper. MIC (Minimum Inhibitory Concentration) value was calculated by plotting $\ln$ Mo (ln of extract concentration) on the $\mathrm{X}$-axis and square of inhibition diameter on the $\mathrm{Y}$ axis. The intersection of the equation on the $\mathrm{X}$-axis was 
the Mt value. MIC value is $0.25 \times \mathrm{Mt}$.

\subsubsection{Toxicity assay}

Toxicity assay was done using Brine Shrimp Lethality Test (BSLT) method (Meyer et al., 1982; Juniarti et al., 2009; Muaja et al., 2013; Puspitasari et al., 2018). A. salina Leach larvae were hatched inside a glass jar by immersing $1 \mathrm{~g}$ of larvae into $100 \mathrm{~mL}$ of seawater and aerated for $48 \mathrm{hrs}$. Eggs were then hatched and the larvae (Nauplii) was ready for assay. About 10-12 shrimp larvae were immersed in $100 \mathrm{~mL}$ of seawater and extracted with a concentration of 10, 100, 200, 500, and $1000 \mathrm{ppm}$ into each jar. As an addition, 2 drops of DMSO were also added into the jar and incubated for 24 hours. Furthermore, the number of dead larvae on each extract concentration that has been added into the jar was calculated and expressed as a percentage of mortality. Extract toxicity was then calculated using Probit.

\subsubsection{Hedonic organoleptic test}

A hedonic test is an organoleptic test in which panellists express their preference towards the given attributes. In this test, panellists were asked to determine their level of preference spontaneously without comparing among samples or comparing to standard (Utiarahman et al., 2013). This test is used to determine panellists preference (Koch et al., 2012) towards chewing gum that has been added with mangrove $B$. gymnorrhyza leaves extract in terms of several attributes, such as colour, taste, texture, and overall acceptance. Hedonic test was done using 5 scales $(1=$ dislike extremely, $2=$ dislike, $3=$ neutral, $4=$ like, $5=$ like extremely) by 70 panelists.

\section{Results and discussion}

\subsection{Antibacterial activity of mangrove Bruguiera gymnorrhyza leaves extract}

Antibacterial activity of $B$. gymnorrhyza leaves extract was measured based on the zone of inhibition and MIC value towards $S$. mutans and $S$. viridans. ANOVA statistical results showed that extract concentration affected the inhibition zone towards $S$. mutans and $S$.

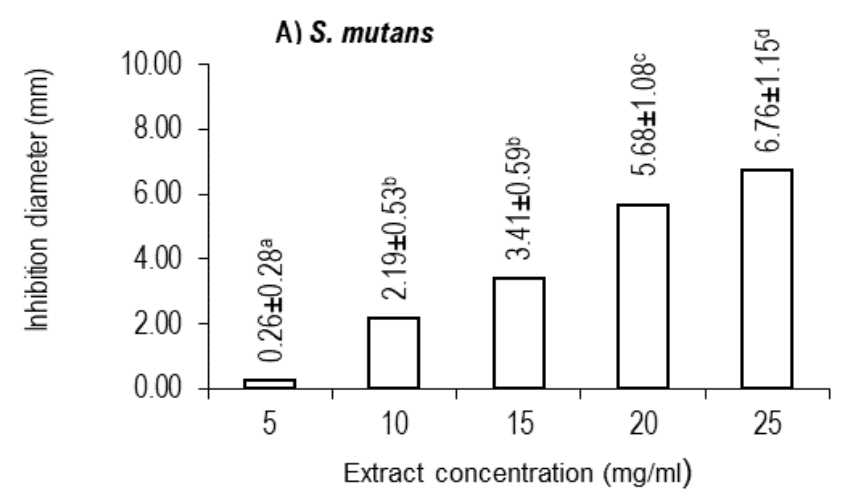

viridans $(\mathrm{p}<0.05)$. Post hoc results using the Tukey test can be observed in Figure 1.

Figure 1 shows that the higher the extract concentration, the larger the zone of inhibition, for both $S$. mutans and $S$. viridans. This indicates that mangrove leaves extract contains antibacterial agent. According to Renaldi et al. (2018), strong antibacterial agents found in Bruguiera were steroid and triterpenoid. A strong antibacterial power of mangrove B. gymnorrhyza leaves extract is shown by an inhibition diameter of $21.4 \mathrm{~mm}$ at extract concentration of $25 \mathrm{mg} / \mathrm{mL}$ towards $S$. viridans. According to Kusmarwati and Indriati (2008) and Rahman et al. (2017), antibacterial activity with inhibition diameter $>20-30 \mathrm{~mm}$ is categorized as very strong, diameter $>10-20 \mathrm{~mm}$ is categorized as strong, the diameter of $5-10 \mathrm{~mm}$ is considered as moderate, and diameter less than $5 \mathrm{~mm}$ is categorized as weak.

Inhibition power of mangrove B. gymnorrhyza leaves extract towards $S$. viridans was much stronger compared to $S$. mutans. This might be caused by the difference in the cell wall structure, even though both bacteria are Gram-positive bacteria. However, the inhibition diameter of mangrove $B$. gymnorrhyza leaves extract towards $S$. mutans $(6.76 \mathrm{~mm}$ per $25 \mathrm{mg} / \mathrm{mL}$ or 2.5 $\mathrm{g} / 100 \mathrm{~mL}$ extract), is stronger than the angsana leaves extract (12.95 mm per $50 \%$ or $50 \mathrm{~g} / 100 \mathrm{~mL}$ extract) (Asfrizal and Masyudi, 2018). Inhibition diameter of mangrove B. gymnorrhyza leaves extract towards $S$. viridans is also much larger $(21.4 \mathrm{~mm}$ per $25 \mathrm{mg} / \mathrm{mL}$ extract) compared to bitter melon leaves extract with an inhibition diameter of $13.27 \mathrm{~mm}$ per $100 \%$ (100 g/100 $\mathrm{mL}$ ) extract (Maharani et al., 2012). Other than concentration, the difference in inhibition diameter is also related to its different bioactive compounds (Suciari et al., 2017; Rahman et al., 2017).

Comparison of antibacterial power based on inhibition diameter might be difficult because it depends on the extract concentration used. Extract concentrations used are often not equal between those being compared. Therefore, a better comparison that can be used might be MIC and MBC (Minimum Bactericidal Concentration)

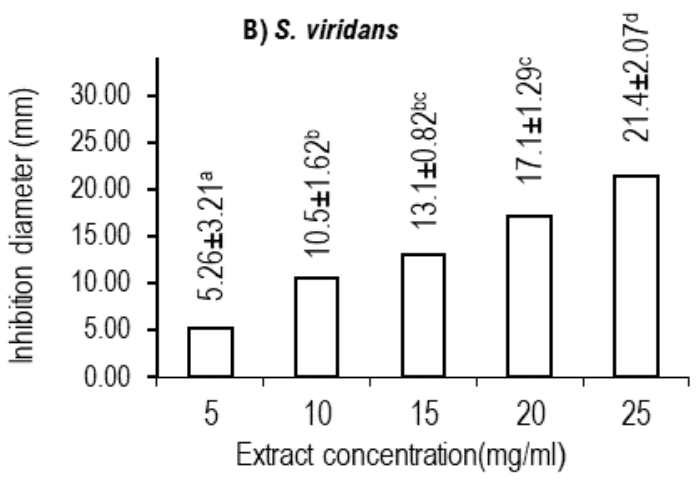

Figure 1. Inhibition diameter of B. gymnorrhyza leaves extract towards (A) Streptococcus mutans dan S. viridans. 
value. Moreover, the antibacterial agent can be categorized as bacteriostatic or bactericidal depending on concentration per certain volume (Fitrial, 2011; Roihanah et al., 2012). MIC results of mangrove $B$. gymnorrhyza leave extract can be seen in Table 1 .

MIC values of mangrove B. gymnorrhyza leave sextract towards $S$. mutans and $S$. viridans is in accordance with their inhibition diameter. The larger the inhibition diameter, the lower the MIC value. MIC value of mangrove B. gymnorrhyza leaves extract towards $S$. mutans is higher compared to noni extract with MIC value of $0.375 \mathrm{mg} / \mathrm{mL}$ (Rifdayani et al., 2014). MIC value of mangrove B. gymnorrhyza leaves extract towards $S$. viridans is also higher compared to bay leaf extract, with an MIC value of $0.12 \mathrm{mg} / \mathrm{mL}$ (Kurnia, 2018), but lower than betel leaf water extract, with MIC value of $15 \%(15 \mathrm{~g} / 100 \mathrm{~mL})(\mathrm{Owu}$ et al., 2020). The difference in MIC value or antimicrobial properties is influenced by the concentration of active compounds and properties of microorganisms (Fitrial, 2011). Even though the MIC value of mangrove B. gymnorrhyza leaves extract is higher compared to noni extract and bay leaf extract, it is still categorized as strong to inhibit dental caries causing bacteria. Thus, it has the potential to be applied to chewing gum.

\subsection{Antibacterial activity of mangrove Bruguiera gymnorrhyza leaves extract chewing gum}

According to Hidayati et al. (2014), chewing gum could stimulate the secretion of saliva, increase $\mathrm{pH}$ of plaque and saliva, making it suitable to be used as a cleanser for the oral cavity. Consumption of chewing gum that contains xylitol about 3 to 5 times a day by chewing it for at least 5 mins after eating could inhibit plaque accumulation and enamel demineralization, increase remineralization at the early stage of caries, and reduce the number of $S$. mutans.

ANOVA statistical results of inhibition diameter showed that mangrove B. gymnorrhyza leaves extract chewing gum affected the inhibition zone $(\mathrm{p}<0.05)$ towards $S$. mutans and $S$. viridans. Post hoc results using the Tukey test can be observed in Figure 2 .
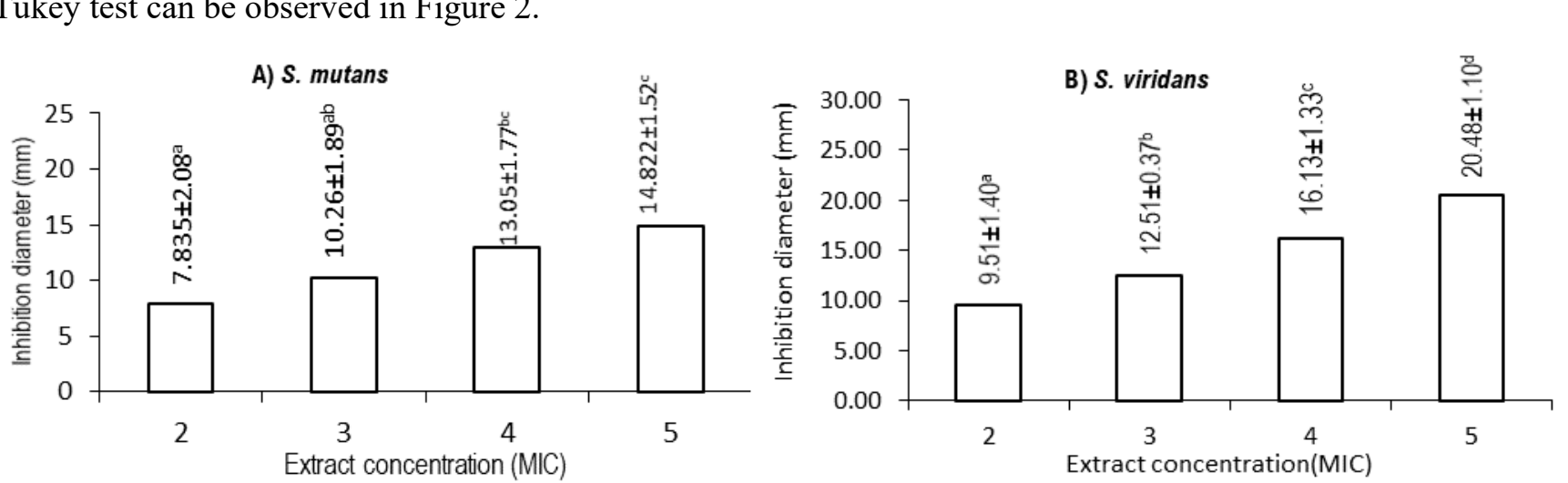

Figure 2. Inhibition diameter of B. gymnorrhyza leaves extract chewing gum towards (A) Streptococcus mutans dan S. viridans.
Inhibition power of chewing gum that is added with mangrove $B$. gymnorrhyza leaves extract shows the same behaviour with its extract, in which higher extract concentration results in a larger inhibition zone. Based on its dosage or concentration and its inhibition diameter, chewing gum has a better inhibition compared to the extract itself. Inhibition diameter of chewing gum added with 5 MIC extract concentration $(5 \times 1.62 \mathrm{mg} / \mathrm{mL}$ $=8.1 \mathrm{mg} / \mathrm{mL}$ ) towards $S$. viridans was $20.48 \mathrm{~mm}$, almost similar to that of extract concentration of $25 \mathrm{mg} / \mathrm{mL}$ which reached $21.40 \mathrm{~mm}$. This result indicates that there is an interaction between extract and other ingredients of chewing gum, such as xylitol. It was also mentioned by Hidayati et al. (2014), chewing gum with xylitol could inhibit plaque accumulation and enamel demineralization, stimulate remineralization in the early stage of dental caries, and decrease the number of $S$. mutans. Inhibition power of chewing gum added with mangrove $B$. gymnorrhyza leaves extract is still stronger compared to chewing gum added with $75 \%$ xylitol which has an inhibition diameter of $9.68 \mathrm{~mm}$ towards $S$. mutans and $10.73 \mathrm{~mm}$ towards $S$. viridans (Kusumaningsari and Handajani, 2011). Based on its inhibition diameter, chewing gum added with mangrove $B$. gymnorrhyza leaves extract has a strong antibacterial activity towards S. mutans (with inhibition diameter of $14.82 \mathrm{~mm}$ at 5 MIC or $8.1 \mathrm{mg} / \mathrm{mL}$ ) and a very strong antibacterial activity towards $S$. viridans $(20.48 \mathrm{~mm}$ at $5 \mathrm{MIC}$ ). The inhibition diameter of this chewing gum is also larger compared to $500 \mathrm{mg} / \mathrm{mL}$ fingerroot extract which has an inhibition diameter of $8.54 \mathrm{~mm}$ towards $S$. mutans (Mahmudah and Atun, 2017) and 75\% cherry leaves extract which has an inhibition diameter of $9.93 \mathrm{~mm}$ towards S. viridans (Sulaiman et al., 2017). According to Mahardika et al. (2014), the difference in inhibition diameter at each concentration is caused by the different amounts of active compounds present in a certain concentration. A higher concentration of extract has a higher amount of active compound, therefore, the inhibition diameter formed would also be different at each concentration (Doughari, 2012). 


\subsection{Hedonic organoleptic results of chewing gum}

An organoleptic hedonic test was done to determine the consumer's preference towards chewing gum that was added with mangrove $B$. gymnorrhyza leaves extract. This result can be seen in Table 3. The preference level towards the colour of chewing gum was not different up to $3 \mathrm{MIC}$ concentrations but decreased at 4 MIC and 5 MIC. This decrease might be caused by the colour of the extract which was dark green which made the colour of chewing gum became darker too. However, up to 3 MIC extract addition, chewing gum was still preferred by panellists. Colour change is also related to different concentrations of mangrove extract added (Paputungan et al., 2014). Colour is important because colour plays a significant role in a food's appearance. Although a portion of food is delicious, if it has an unappealing appearance when served, it could decrease a person's appetite to consume it (Soeparno, 2005). The higher the concentration of extract, the colour of a food product will be more similar to the colour characteristics from the extract used.

Table 3. Hedonic value of B. gymnorrhyza leaves extract chewing gum

\begin{tabular}{ccccc}
\hline \multirow{2}{*}{$\begin{array}{c}\text { Extract } \\
\text { concentration }\end{array}$} & \multicolumn{4}{c}{ Hedonic score } \\
\cline { 2 - 5 } 2 MIC & $3.5 \pm 0.0^{\mathrm{a}}$ & $3.2 \pm 0.3^{\mathrm{a}}$ & $3.2 \pm 0.7^{\mathrm{a}}$ & $3.4 \pm 0.0^{\mathrm{a}}$ \\
$3 \mathrm{MIC}$ & $4.0 \pm 0.4^{\mathrm{a}}$ & $4 \pm 0.5^{\mathrm{a}}$ & $3.0 \pm 0.0^{\mathrm{a}}$ & $4.0 \pm 0.5^{\mathrm{b}}$ \\
$4 \mathrm{MIC}$ & $3.0 \pm 0.4^{\mathrm{b}}$ & $2.9 \pm 0.5^{\mathrm{b}}$ & $2.9 \pm 0.9^{\mathrm{a}}$ & $3.2 \pm 0.3^{\mathrm{c}}$ \\
$5 \mathrm{MIC}$ & $2.9 \pm 0.5^{\mathrm{b}}$ & $2.8 \pm 0.4^{\mathrm{b}}$ & $2.9 \pm 0.8^{\mathrm{a}}$ & $3.1 \pm 0.5^{\mathrm{c}}$ \\
\hline
\end{tabular}

Values are presented as mean \pm SD. Values with different superscript within the same column are significantly different $(\mathrm{p}<0.05)$.

In terms of taste, the hedonic test showed a similar pattern of preference, in which up to 3 MIC extract was added into chewing gum, the preference is similar, but after $4 \mathrm{MIC}$, the preference towards chewing gum's taste decreases. A decrease of preference towards chewing gum is related to the astringent taste of extract, caused by high tannin content in mangrove plants (Hardoko et al., 2015). Taste is an important parameter to determine acceptance of a certain product. Even though a food product is highly nutritious, if it has an unwanted taste, it will be rejected by the panellists (Winarno, 2002). Moreover, astringency from extract could decrease the sweet taste of chewing gum (Palupi and Widyaningsih, 2015; Pujilestari and Agustin, 2017).

On the other hand, panellists' preference towards the texture of chewing gum was not significantly different, which means that extract addition did not affect the texture of chewing gum. The texture of chewing gum is more influenced by the type and amount of gum base and sucrose added, meanwhile hard candy is more influenced by sucrose crystal formation (Jalasena and Anjani, 2016), resulting from mixing sucrose and glucose syrup (Ward and Courts, 1977). Other factors that affect the texture of candy are the addition of gelatin, water, citric acid, heating process, and all ingredients should be added in the same amount at the same time and temperature (Riyawan et al., 2016).

The overall acceptance parameter is used in the hedonic test to determine and measure panellists' preference towards the whole attributes in a product (Gustiari, 2009). In terms of overall acceptance, chewing gum has increasing preference up to 3 MIC extract addition, then decreasing at a higher concentration of extract added. It was suspected that overall acceptance is also related to the taste and colour of chewing gum. The taste of chewing gum is related to the astringent taste from the tannin in mangrove B. gymnorrhyza extract. The dark green colour of chewing gum could be influenced by chlorophyll colour and brown colour from carotenoids and other pigments. A combination of those colours creates a dark colour (Ridlo et al., 2017).

\subsection{The selected treatment and chewing gum toxicity}

Although chewing gum in this research was intended to inhibit dental caries causing bacteria, inhibition power cannot be a determining factor, but acceptance or preference level was the determining factor to select the best treatment. Chewing gum with the highest preference was the one added with 3 MIC mangrove $B$. gymnorrhyza leaves extract $(4.86 \mathrm{mg} / \mathrm{mL})$.

On the selected chewing gum, a toxicity assay was done using BSLT to obtain $\mathrm{LC}_{50}$ value. Based on BSLT method, a sample is considered toxic if it has $\mathrm{LC}_{50}$ less than $100 \mathrm{mg} / \mathrm{mL}$ (Meyer et al., 1982). LC L $_{50}$ of chewing gum added with 3 MIC of mangrove $B$. gymnorrhyza leaves extract was $10502 \mathrm{mg} / \mathrm{mL}$, therefore it is considered non-toxic.

\section{Conclusion}

Inhibition of mangrove $B$. gymnorrhyza leaves extract towards dental caries causing bacteria is categorized as strong with MIC value of $1.62 \mathrm{mg} / \mathrm{mL}$ towards $S$. mutans and $1.35 \mathrm{mg} / \mathrm{mL}$ towards S. viridans. The selected and most preferred addition of mangrove $B$. gymnorrhyza leaves extract in chewing gum is at $3 \mathrm{MIC}$ concentration $(4.86 \mathrm{mg} / \mathrm{mL})$ at a preference level of 4.0 (out of 5.0) and inhibition diameter towards S. mutans of $10.26 \mathrm{~mm}$ and $S$. viridans of $12.51 \mathrm{~mm}$, with $\mathrm{LC}_{50}$ value of $10502 \mathrm{mg} / \mathrm{mL}$. 


\section{Conflict of interest}

We declare no conflict of interest with the data contained in this manuscript. The authors hereby declare that the work presented in this article is original and that any liability for claims relating to the content of this article will be borne by them.

\section{References}

Abeysinghe, P.D. (2010). Antibacterial activity of some medicinal mangroves against antibiotic resistant pathogenic bacteria. Indian Journal of Pharmaceutical Science, 72(2),149-282. https:// doi.org/10.4103/0250-474X.65019

Abubakar, S., Kadir, M.A., Wibowo, E.S. and Akbar, N. (2019). Benefits of mangroves for the designation of pharmaceutical preparations in Mamuya Village, Galela District, East Halmahera Regency (Ethnopharmacological Review). Jurnal Enggano, 4 (1),12-25. https://doi.org/10.31186/jenggano.4.1.1225

Adi, V.Z. and Usman, P. (2017). Anti-fungal potential of Bruguiera gymnorrhyza mangrove leaf menthanol extract against Candida albicans and Asperilgus niger. Jurnal Kimia Mulawarman, 15(1), 29-37. https://doi.org/10.30872/jkm.v15i1.583

Alhaddad, Z.A., Wahyudi, D. and Tanod, W.A. (2019). Antibacterial bioactivity of mangrove leaf extracts Avicenia sp. Indonesian Journal of Marine Science and Technology, 12(1), 12-22. https:// doi.org/10.21107/jk.v12i1.4752

Asfrizal, V. and Masyudi. (2018). Antibacterial activity of ethanol extract of leaves, bark and sap of Angsana (Pterocarpus indicus Willd) against the growth of Streptococcus mutans. Jurnal Kedokteran Gigi, 5(1), 1-7. https://doi.org/10.30659/odj.5.1.1-8

Astuti, P. and Meilawaty, Z. (2013). Antibacterial effect of toothpaste containing tea free oil against $S$. aureus, $S$. mutans, and $S$. viridans bacteria. Stomatognatic, 10(3), 121-124.

Audah, K.A., Batubara, R., Julkipli, Wijaya, E., Kurniawaty, E. and Batubara, I. (2020). Antibacterial Screening of mangrove extract library showed potential activity against Escherichia coli and Staphylococcus aureus. Journal of Tropical Life Science, 10(2), 105 - 111. https://doi.org/10.11594/ jtls.10.02.03

Bloomfield, S.F. (1991). Assessing Antimicrobial Activity. In Denyer S.P. and Hugo W.B. (Eds), Mechanism of Action of Chemical Biocides. Oxford: Blackwell Scientific Publication.

Ciptaningrum, I. and Putri, R.A. (2019). Antibacterial effect of toothpaste containing tea free oil against $\mathrm{S}$. aureus, S. mutans, and S. viridans bacteria. Jurnal
Farmasetis, 8(2), 75 - 82. https://doi.org/10.32583/ farmasetis.v8i2.626

Cotti, E., Dessì, C., Piras, A. and Mercuro, G. (2011). Can a chronic dental infection be considered a cause of cardiovascular disease? A review of the literature. International Journal of Cardiology, 148(1), 4-10. https://doi.org/10.1016/j.ijcard.2010.08.011

Doughari, J.H. (2012). Phytochemicals: Extraction Methods, Basic Structures and Mode of Action as Potential Chemotherapeutic Agents. In Rao, V. (Eds), Phytochemicals, A Global Perspective of Their Role in Nutrition and Health, p. 8-9. IntechOpen E-Book.

Fatmawati, D.W.A. (2015). The relationship of Streptococcus mutans biofilms to the risk of developing dental caries. Stomatognatic, 8(3), 127130.

Fitrial, Y. (2011). The effect of heating temperature on antibacterial activity of Water Lily (Nymphaea pubescens Willd) seed ethyl acetate extract. Jurnal Pengolahan Hasil Perikanan Indonesia, 14(1), 4348.

Gustiari, E. (2009). Control of microbial contamination in foodstuffs from livestock (Meat and Milk) from the farm to serving. Journal of Agricultural Research and Development, 28(3), 96-100.

Haerazi, A., Dwi, S.D.J. and Yayuk, A. (2014). Kencur (Kaemferia galangal L.) extract antibacterial activity test against the growth of Staphylococcus aureus and Streptococcus viridans bacteria. Bioscientist Jurnal Ilmiah Biologi, 2(1), 1-11.

Hastarini, E., Rosulva, I. and Haryadi Y. (2014). Characteristics of Vannamei peeled shrimp with the addition of an edible coating made from chitosan and lindur extract (Bruguiera gymnorrhiza) during storage. Jurnal Pascapanen dan Bioteknologi Kelautan dan Perikanan, 9(2), 175-184. https:// doi.org/10.15578/jpbkp.v9i2.110

Hidayati, N.A., Kaidah, S. and Sukmana, B.I. (2014). The effect of chewing gum containing xylitol on the increase in $\mathrm{pH}$ of saliva. Jurnal Kedokteran Gigi, 3 (1), 51-55.

Hardoko, Suprayitno, E., Puspitasari, Y.E. and Amalia, R. (2015). Study of ripe Rhizophora mucronata fruit flour as functional food for antidiabetic. International of Food Research Journal, 22(3), 953959.

Jacoeb, A.M., Suptijah, P. and Zahida. (2013). Chemical composition, bioactive component and antioxidant activity of Large-Leafed Mangrove (Bruguiera gymnorrhiza) fruit. JPHPI, 16(1), 86-94.

Jalasena, R.A. and Anjani, G. (2016). Antioxidant activity, physical properties, and acceptability of 
marshmallows with the addition of broccoli. Journal of Nutrition College, 5(1), 20-27.

Juniarti, D.O. and Yuhernita. (2009). Chemical toxicity test compounds (Brine Shrimp Lethality Test) and antioxidants (1,1-diphenyl-2- picrylhydrazyl) from Saga leaf extract (Abrus precatorius L). Makara Sains, 13(1), 50-54. https://doi.org/10.7454/ mss.v13i1.378

Kassebaum, N.J., Smith, A.G.C., Fleming B.T.D., Reynolds, A.E., Vos, T., Murray, C.J.L. and Marcenes, W. (2017). Global, Regional, and National Prevalence, Incidence, and DisabilityAdjusted Life Years for Oral Conditions for 195 Countries, 1990-2015: A Systematic Analysis for the Global Burden of Diseases, Injuries, and Risk Factors. Journal of Dental Research, 96(4), 380-387. https://doi.org/10.1177/0022034517693566

Khairani, K., Busman and Edrizal. (2017). Antibacterial activity test of white oyster mushroom extract (Pleurotus ostreatus) against Streptococcus mutans bacteria that causes dental caries. Jurnal B-Dent, 4 (2), 110 - 116. https://doi.org/10.33854/JBDjbd.102

Koch, L.S., Mull, S., Joubert, E., Rijst, V.D. and Naes, T. (2012). Sensory characterization of rooibos tea and the development of a rooibos sensory wheel and lexicon. Food Research Intertantional, 46, 217-228. https://doi.org/10.1016/j.foodres.2011.11.028

Kusumaningsari, V. and Handajani, J. (2011). The effect of chewing sugar and xylitol gum on the growth of Streptococcus mutans bacteria in dental plaque. Majalah Kedokteran Gigi, 18(1), 30-34. https:// doi.org/10.22146/majkedgiind.16473

Kurniasih, N. and Halimah, E. (2019). Review Article: Antibacterial activity of extracts of various species of mangrove plants. Farmaka, 17(2), 359-366.

Kurnia, Y.A.S. (2018). Anticariogenic activity of bay leaf extract (Syzygyum polyanthum (Wight) Walp) against types of bacteria that cause dental caries. Jurnal Teknik Unpas, 1(2), 5-12.

Kusmarwati, A. and Indriati, N. (2008). Inhibition of the extract of the active ingredient of Picung seeds (Pangium edule Reinw.) against the growth of histamine-producing bacteria. Jurnal Pascapanen dan Bioteknologi Kelautan dan Perikanan, 3(1), 2936.

Maharani, R.D., Praharani and Purwanto. (2012). Antibacterial activity of Pare leaf (Momordica charantia) extract on inhibition of Streptococcus viridans growth. Jurnal Kedokteran Gigi, 1(2), 1-7.

Mahardika, H.A., Sarwiyono and Surjowardojo, P. (2014). Cherry leaf methanol extract (Muntingia calabura L) as a natural antimicrobial against Staphylococcus aureus bacteria which causes subclinical mastitis in dairy cows. Jurnal Ternak Tropika, 15(2), 15-22.

Mahmudah, F.L. and Atun, S. (2017). Antibacterial activity test of Temukunci (Boesenbergia pandurata) ethanol extract against Streptococcus mutans bacteria. Jurnal Penelitian Saintek, 22(1), 59-66. https://doi.org/10.21831/jps.v22i1.15380

Meyer, B.N., Ferrigni, N.R., Putman, J.E., Jacobsen, L.B., Nichols, D.E. and Mclaughilin, J.L. (1982). Brine shrimp: a convenient general bioassay for active plant constitutents. Journal Medical Plant Research, 4(1), 31-34. https://doi.org/10.1055/s2007-971236

Mikchaell, A.P., Suprayitno, E. and Hardoko. (2018). Antibacterial compound activity of mangrove leaf extract Rhyzophora mucronata on Aeromonas hydrophyla. Russian Journal of Agricultural and Socio-Economic Sciences, 1(73), 187-193. https:// doi.org/10.18551/rjoas.2018-01.24

Muaja, A., Koleangan H.S.J. and Runtuwene, M.R.J. (2013). Toxicity test using the BSLT method and analysis of the phytochemical content of soyogic leaf extract (saurauia bracteosa DC) using the Soxhletation method. Jurnal MIPA, 2(2), 115-118. https://doi.org/10.35799/jm.2.2.2013.3000

Mustopa, A.Z., Umami, R.N. and Melki. (2015). Antibacterial activity assay of mangrove extracts againt Salmonella typhi and Listeria monocytogenes. Jurnal Ilmu dan Teknologi Kelautan Tropis, 7(2), 603-612. https://doi.org/10.29244/jitkt.v7i2.11029

Newman, M.G., Takei, H.H., Klokkevoid, P.R. and Carranza, F.A. (2006). Clinical Periodontology, $10^{\text {th }}$ Ed., p. 241-245. St Louis, USA: Saunders.

Owu, N.M., Fatimawali and Jayanti, M. (2020). Inhibition effectiveness test of Betel leaf extract (Piper betle L.) against Streptococcus mutans bacteria. Jurnal Biomedik, 12(3),145-152.

Paksi, P.I.L., Sugihartana, D. and Larnani, S. (2018). Inhibitory effect of aqueous extract of Ocimum basilicum leaves on Streptococcus mutans In Vitro. Jurnal Kedokteran Brawijaya, 30(2), 87-91. https:// doi.org/10.21776/ub.jkb.2018.030.02.2

Palupi, R.M. and Widyaningsih, T.K. (2015). Manufacture of functional beverage tea leaves (Eugenia polyantha) with the addition of ginger filtrate and Secang wood filtrate. Jurnal Pangan dan Agroindustri, 3(4), 42- 46.

Paputungan, F., Yamlean, P.V.Y. and Citraningtyas, G. (2014). Test the effectiveness of black mangrove leaf ethanol extract saleb (Bruguiera gymnorrhyza) and test the healing process of rabbit back wounds infected with Staphylococcus aureus bacteria. Jurnal Ilmiah Farmasi, 3(1), 15-26. 
Parhusip, A.J.N. and Sitanggang, A.B. (2011). Antimicrobial activity of melinjo seed and peel extract (Gnetum gnemon) against selected patoghenic bacteria. Microbiology Indonesia, 5(3), 103-112. https://doi.org/10.5454/mi.5.3.2

Pujilestari, S. and Agustin, I. (2017). Quality hard candy with different concentrations of green tea extract. Jurnal Konversi, 6(2), 55-64. https:// doi.org/10.24853/konversi.6.2.9

Purnamasari, D.A., Munadziroh, E. and Yogiartono, R.M. (2010). Concentration of cocoa bean extract as material and in inhibiting the growth of Streptococcus mutans. Jurnal PDGI, 59(1), 14-18.

Purnobasuki, H. (2004). Prospect of Mangrove as Herbal Medicine. Biota, 9(2), 24-126.

Puspitasari, E., Rozirwan, and Hendri, M. (2018). Toxicity test using the Brine Shrimp Lethality Test (Bslt) method on mangrove extracts (Avicennia marina, Rhizophora mucronata, Sonnerratia alba, and Xylocarpus granatum) originating from Banyuasin, South Sumatra. Jurnal Biologi Tropis, 18 (1), 91- 103. https://doi.org/10.29303/jbt.v18i1.733

Rahman, F.A., Haniastuti, T. and Utami, T.W. (2017). Phytochemical screening and antibacterial activity of ethanol extract of soursop (Annona muricata L.) leaves on Streptococcus mutans ATCC 35668. Majalah Kedokteran Gigi Indonesia, 3(1), 1-7. https://doi.org/10.22146/majkedgiind.11325

Raithore, S. and Peterson. D.G. (2018). Effect of polyol type and particle size on flavor release in chewing gum. Journal of Food Chemistry, 1(1), 293-299. https://doi.org/10.1016/j.foodchem.2018.01.123

Ramayanti, S. and Purnakarya, I. (2013). The role of food on the incidence of dental caries. Jurnal Kesehatan Masyarakat, 7(2), 89-93.

Renaldi, Rozirwan, and Ulqodry, T.Z. (2018). The bioactivity of bioactive compound in mangrove Avicennia marina and Bruguiera gymnorrhiza as antibacterial from Payung Island and Tanjung Apiapi. Maspari Journal: Marine Science Research, 10 (1), 73-80.

Rifdayani, N., Budiarti, L.Y. and Carabelly, A.N. (2014). Comparison of the bactericidal effect of $100 \%$ noni (Morinda citrifolia Liin) extract and $1 \%$ povidone iodine against in vitro Streptococci mutant. Jurnal Kedoketran Gigi, 11(1), 1-6.

Ridlo, A., Pramesti, R., Koesoemadji, Supriyantini, E. and Soenardjo, N. (2017). Antioxidant activity of Rhizopora mucronata mangrove leaf extract. Buletin Oseanografi Marina, 6(2), 110-116. https:// doi.org/10.14710/buloma.v6i2.16555

Riyawan, F., Mustofa, A. and Kurniawati, L. (2016). Antioxidant activity of jelly candy with variation of secang wood (Caesalpinia sappan L.) extract concentration and extraction time. Jurnal Teknologi dan Industri Pangan, 1(1), 35-40.

Roihanah S., Sukoso and Andayani, S. (2012). Antibacterial activity of Sea Cucumber extract Holothuria sp. against Vibrio harveyi bacteria In vitro. Journal Experiment and Life Science, 2(1), 15. https://doi.org/10.21776/ub.jels.2012.002.01.01

Saad, S., Taher, M., Susanti, D., Qaralleh, H. and Rahim, N.A.B.A. (2011). Antimicrobial activity of mangrove plant (Lumnitzera littorea). Asian Pacific Journal of Tropical Medicine, 4(7), 523-525. https:// doi.org/10.1016/S1995-7645(11)60138-7

Siregar, T., Dhiksawan, F.S. and Farida, A. (2011). Growth of Streptococcus mutans on the in vitro bioactivity of galangal rhizome extract and its utilization as an active substance in toothpaste. Jurnal Kimia, 5(1), 9-23.

Soeparno. (2005). Meat Science and Technology. 4th Eds. Yogyakarta, Indonesia: Gadjah Mada University Press.

Suciari, L.K., Mastra, N. and Widhya, C.D. (2017). Differences in the growth inhibition zone of Staphylococcus aureus at various concentrations of bay leaf decoction (Syzygium polyanthum) by in vitro. Meditory (The Journal of Medical Laboratory), 5(2), 92-100.

Suhendar, U. and Fathurrahman, M. (2019). Antibacterial activity of clove flower (Syzygium aromaticum) methanol extract against Streptococcus mutans bacteria. Fitofarmaka, 9(1), 26-34. https:// doi.org/10.33751/jf.v9i1.1257

Sulaiman, A.Y., Astuti, P. and Shita, A.D.P. (2017). Antibacterial test of Kersen leaf extract (Muntingia Calabura L.) against Streptococcus viridians colonies. Indonesian Journal for Health Sciences, 1 (2), 1-6. https://doi.org/10.24269/ijhs.v1i2.590

Sumardi, Basyuni, M. and Ridhawati. (2018). Antimicrobial activity of polyisoprenoids of sixteen mangrove species from North Sumatra, Indonesia. Biodiversitas, 19(4), 1243-1248. https:// doi.org/10.13057/biodiv/d190409

Utiarahman, G., Harmain, R.M. and Yusuf, N. (2013). Chemical and organoleptic characteristics of flying fish nuggets (Decapterus sp.) substituted with white sweet potato flour (Ipomea batatas L). Jurnal Ilmu Perikanan dan Kelautan, 1(3), 126- 139.

Ward, A.G. and Courts, A. (1977). The Science of Technology of Gelatin, p. 564. London: Academic Press.

Winarno, F.G. (2002). Food Chemistry and Nutrition, p. 253. Jakarta, Indonesia: PT. Gramedia Pustaka Utama. 